\title{
感電による労働災害の現状と海外の 交流アーク溶接機用安全装置との比較調査
}

冨田 - *1, 崔 光 石*2

休業 4 日以上の感電に起因する労働災害を厚生労働省の労働災害（死亡・休業 4 日以上）データベースを用 いて平成18２7年の10年間を分析した結果, 定性的な状況は平成 10 年以前と感電災害の多く発生している業種, 発生月, 感電災害を誘引した起因物などに変化の無いことを明らかにした。

感電災害の起因物として上位を占めるアーク溶接機について，感電災害防止対策用の安全装置である交流 アーク溶接機用自動電撃防止装置と同様の機能を有する安全装置を韓国, オーストラリアと比較した. その結果, 始動感度, 遅動時間, 安全電圧の仕様には大きな差の無いことを明らかにした.

キーワード：感電，労働災害データベース，交流アーク溶接機, 交流アーク溶接機用自動電撃防止装置, 危険低減装置, 韓国とオーストラリア

\section{1 はじめに}

事故の型別にみた休業 4 日以上の労働災害では, 感電 に起因する労㗢災害の発生件数は労㗢災害全体の中では 下位に位置するが, 災害発生件数に占める死亡災害の発 生件数では上位に位置している.すすおち感電災害は一 度災害が発生すると死亡に至る可能性が高い特徴を有し ている.

本稿では厚生労㗢省の労衝災害データベースを用いて 平成 18 年から 10 年間の感電に起因する休業 4 日以上の 死傷災害を, 業種, 起因物, 労働者の規模, 発生月, 被 災者の年齢によって分析した. その結果, 平成 10 年以 前と比較して発生件数は減少したものの, 定性的な状況 は基本的には変化のないことを明らかにした.

また, 起因物として上位を占めるアーク溶接機に使用 される交流アーク溶接機用自動電撃防止装置（以下, 「電 撃防止装置」という.）について, 韓国, オーストラリ アとの比較を行った。 その結果, 日本の電撃防止装置と 韓国, オーストラリアのアーク溶接機用の感電防止安全 装置とには大きな差の無いことを明らかにした.

\section{2 感電による労働災害の統計結果}

厚生労働省の運営する職場の安全サイト ${ }^{1)}$ にある労働 災害（死亡・休業4日以上）データベースにおいて，平 成 18 年から平成 27 年までの 10 年間に発生した休業 4 日 以上の労働災害のうち，災害発生年ごとに抢よそ $1 / 4$ を 無作為に抽出した個別事例を用いて, 感電（含む落雷） によって死傷した 286 人の労働災害を分析した。

図 1 に示すように 286 人の感電死傷者数の内, 建設業 では 123 人 $(43 \%)$, 製造業では 82 人 $(29 \%)$ となり, これらが全体の $72 \%$ と大半を占めていた，その他の業

原稿受付 2018年 9 月26日 (Received date: September 26, 2018) 原稿受理 2018年11月28日 (Accepted date: November 28, 2018)

J-STAGE Advance published date: January 16, 2019

*1 労働安全衛生総合研究所研究推進・国際センター

*2 労働安全衛生総合研究所電気安全研究グループ

連絡先：干204-0024 東京都清瀬市梅園 1-4-6

労働安全衛生総合研究所研究推進・国際センター 冨田一

E-mail: tomita@s.jniosh.johas.go.jp

doi: 10.2486/josh.JOSH-2018-0011-CHO
種としては，合計 81 人で，鉱業（1人），運輸交通業（9 人), 農林業 ( 2 人), 畜産・水産業 ( 3 人), 商業 ( 13 人), 通信業 ( 1 人), 教育・研究業 $(12$ 人), 保健・衛生業 $(7$ 人), 接客娛楽業 $(10$ 人), 清掃・と畜業 $(16$ 人), その 他の事業（18人）であった.

図 2 に示すように，労働者数で規模を見ると，1９人 の規模で 94 人 $(33 \%), 10 \sim 29$ 人の規模で 71 人 $(25 \%)$, $30 \sim 49$ 人の規模で 37 人 $(13 \%), 50 \sim 99$ 人の規模で 34 人 $(12 \%), 100 \sim 299$ 人の規模で 31 人 (11\%) であった. このように1〜9人，10～ 29 人の規模で $58 \%$ と過半数を 占めている状況であった.
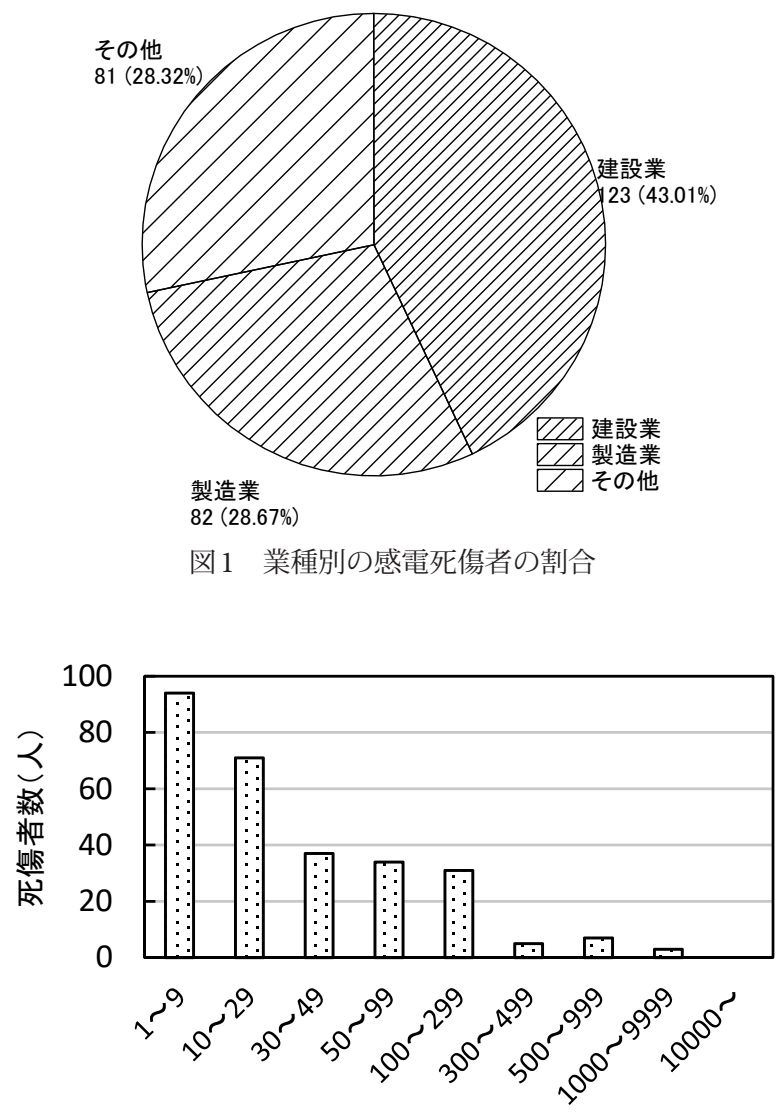

労働者数の規模 (人)

四2 規模別の感電死傷者数 
図3のように感電災害の起因物としては, 電力設備 (死 傷者数: 85 人), 送配電線等 $(72$ 人), その他の電気設 備 $(30$ 人), その他の装置, 設備 ( 22 人), アーク溶接 機（17人）の順となっている. 電力設備, 送配電線等 は従来より起因物の多くを占めているが, アーク溶接機 も第5位と上位となっている．これらを合わせた死傷者 数は 226 人と $79 \%$ を占めていることが分かる.

月別の感電死傷者数を図 4 に示す. 8 月が 60 人と最多 で, 次いで 9 月の 39 人, 7 月の 36 人, 6 月の 34 人と続い ている. 6 9月の合計で 169 人と全体の $59 \%$ を占めて おり，夏季に集中していることが確認できた，夏季に感 電災害が多発する要因としては, 発汗に伴って人体抵抗 が低下すること, 肌を露出する可能性が高まること, 高 温のために集中力が低下することが挙げられている.

図 5 には年齢別の感電死傷者数を示す. 36 才が 13 人, 次いで 37 及び 63 才の 12 人, 30 才の 11 人と続いている. 30 代後半からは概略減少の傾向であったが，63才で 12 人と突出している状況であった. 今後 $36,37,63$ 才で の感電災害が特別の要因か否かを検討する必要があると 考えられるが, 現時点では要因は不明である.

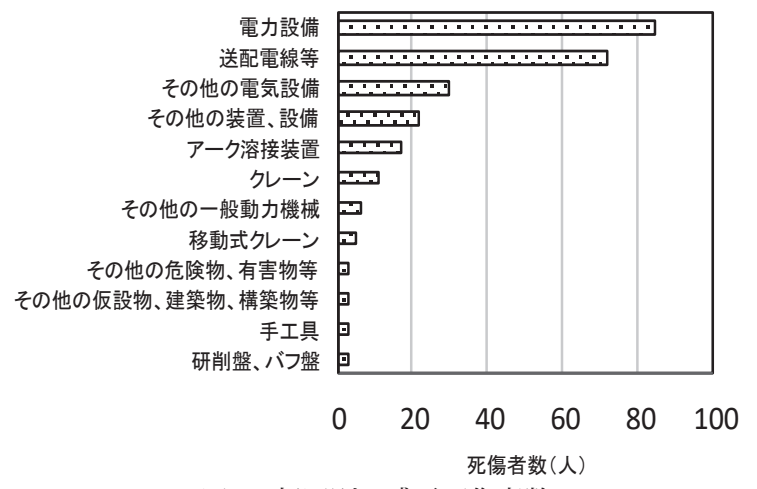

図3 起因別の感電死傷者数

\section{3 アーク溶接機用安全装置の国際比較}

前章での感電災害の統計結果の通り, アーク溶接機を 起因物とする感電災害は全体の第 5 位に位置している. アーク溶接機による感電災害防止には, 安全装置である 電撃防止装置が労働安全衛生法第 20 条を根拠とした労 働安全衛生規則第 332 条に基づき使用されている. 電撃 防止装置は, 労㗢安全衛生法第 42 条を根拠として厚生 労働大臣が定める規格を具備しなければ設置等ができな いものであり, 具備すべき規格は, 交流アーク溶接機用 自動電撃防止装置構造規格（以下,「構造規格」という.） に定められている. 電撃防止装置の感電災害防止の一層 の向上を目的として, 平成 23 年には始動感度が構造規 格に取り入れられた。

電撃防止装置はアーク溶接作業での感電災害防止に寄 与しているが, 日本以外でのアーク溶接作業での感電防 止のための対策技術について, 韓国, オーストラリアを 対象とし, 電撃防止装置の安全性に関わる項目を中心と して比較調查した.

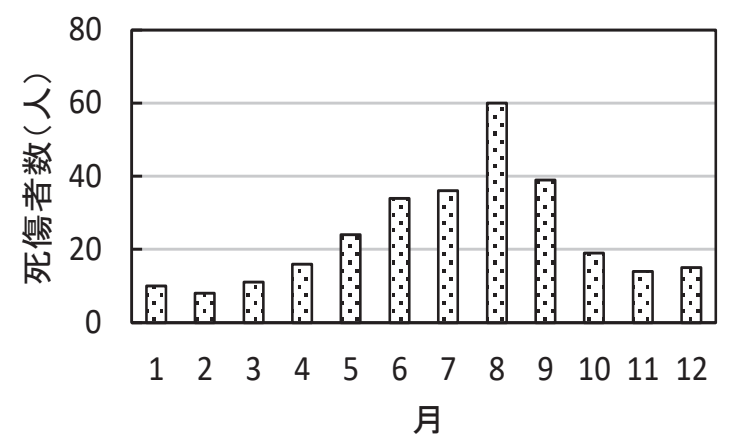

図4 月別の感電死傷者数

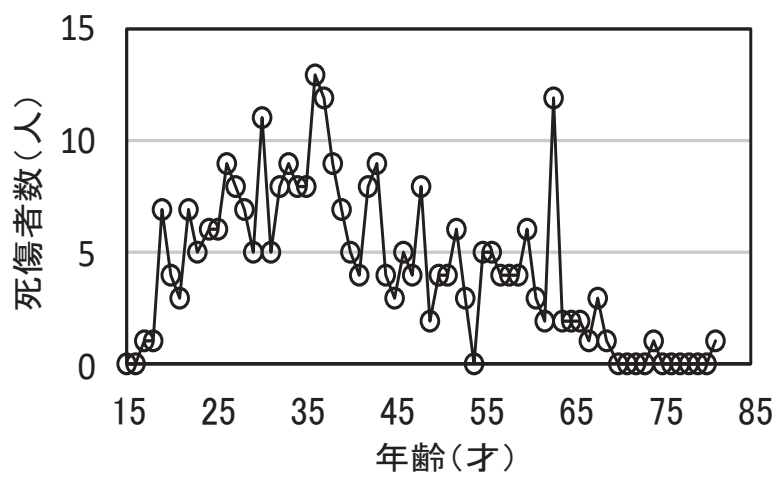

図 5 年齢別の感電死傷者数

\section{1）韓国の場合}

韓国労働省の労働安全衛生法第23条の (安全対策) において, 事業主は業務上の電気, 熱, その他のエネル ギーに起因する危険を防止するために必要な対策を講ず ることが求められている.

労働安全衛生法第23条に基づき「労働安全衛生基準 に関する規則」第306条（交流アーク溶接機など）にお いては，事業者は，次の各号に掲げる場所で交流アーク 溶接機（自動溶接を除く）を使用する場合には，交流ア ーク溶接機に電撃防止装置を設置しなければならないと されている.

（1）船舶の二重船体内部, 若しくは Ballastタンク, 若しくはボイラー内部等導電体に囲まれた場所

（2）墜落する危険性がある高さ $2 \mathrm{~m}$ 以上の場所で鉄骨 等導電性の高い接地物に労㗢者が接触するおそ れがある場所

（3）作業員が水，発汗などで導電性が高く湿気の多い 状態で作業する場所

上記の（1），(2）は日本の労働安全衛生規則第332条 と同様であるが, (3) は日本では特段定められていない. な押, 労㗢安全衛生総合研究所の技術指針と類似した位 置づけにある「アーク溶接機の設置及び使用に関する技 術指針（KOSHA GUIDE E-76-2013, 韓国産業安全保 健公団, 2013年11月改訂)」においても, 電擊防止装置 の必要な場所が同様に定められている.

電撃防止装置の構造については, 保護装置自立安全基 準公示（韓国労働部公示第2015-94号：2015.12.24一部 改訂）の第3章 交流アーク溶接機 電撃防止装置 第 2節 性能基準及び試験方法 第 5 条において「電撃防 
止装置の性能基準および試験方法」として定められ, 具 体的には[別表 2$]$ 電撃防止装置の性能基準（第 5 条関連） 及び [別表 2-2]電撃防止装置の試験方法（第 5 条関連） で規定している.

電撃防止装置の安全に関わる項目には安全電圧, 遅動 時間, 始動感度, 耐衝撃性, 絶縁抵抗がある. 表 1 の比 較表に示すように, 多少の差があるものの大差はみられ ない，具体的には，日本，韓国において，安全電圧はそ れぞれ $30 \mathrm{~V}$ 以下， $25 \mathrm{~V}$ 以下 (接点方式)，始動感度はそ れぞれ $260 \Omega$ 以下， $200 \Omega$ 以下，遅動時間はそれぞれ 1.5 秒以内, 1.0 秒以内となっている. ただし, 韓国では電 磁ノイズに対する試験として, Tig 高圧発生装置をノイ ズ試験として取り入れ， $5 \mathrm{kV}$ の高圧パルスを 1 秒間隔で 10 回の印加方法が取り入れられているが，日本では電 磁ノイズに対する試験は特段定められていない。

\section{2）オーストラリアの場合}

オーストラリアの労働安全衛生の法律には, Work Health and Safety Act（労働安全衛生法）(WHS Act) 2011があり, その中の Division 2-Codes of practice（実 施指針）では，274 Approved codes of practice（公認の 実施指針）として，次のように記述されている。

(1) The Minister may approve a code of practice for the purposes of this Act and may vary or revoke an approved code of practice.

(大臣はこの法律の目的のために実施指針を承認 し, また承認された実施指針を改訂あるいは廃止 することがある)

（1）では大臣はこの法律のために実施指針を認可し, 当該指針を改訂，あるは廃止する，とされている.

この法律に基づき, Welding processes Code of Practice（溶接作業の実施指針）が Safe Work Australia より発行されている. Safe Work Australiaは 2009年に 設立されたオーストラリア政府の法的な代理権を有する 機関である. Safe Work Australiaは 州，地域からのメ ンバー，労使代表者を含んでいる．この指針の序文には 次のように記述されている.

This Code of Practice on how to manage the risks associated with welding processes in the workplace is an approved code of practice under section 274 of the Work Health and Safety Act (WHS Act).

（作業現場での溶接作業に付随したリスクをいかに报 うかに関わるこの実施指針は労働安全衛生法第 274 に 基づいて承認されたものである)

Welding processes Code of Practice の 3.3.Electrical risks（電気的なリスク）では, 感電防止のための対策 が記述され，この指針以外のガイドとして，次が紹介さ れている。

- Code of Practice: Managing electrical risks in the workplace

- Welding Electrical Safety, WTIA Technical Note No. 22, published by the Welding Technology Institute of Australia
表 1 日本, 韓国, オーストラリアのアーク溶接機用感電防止 安全装置の比較

\begin{tabular}{|c|c|c|c|}
\hline & 日本 & 韓国 & オーストラリア \\
\hline $\begin{array}{l}\text { 安全 } \\
\text { 電压 }\end{array}$ & $30 \mathrm{~V}$ 以下 & $\begin{array}{l}25 \mathrm{~V} \text { 以下（接点 } \\
\text { 方式), } 15 \mathrm{~V} \text { 以下 } \\
\text { (無接点方式) }\end{array}$ & $\begin{array}{l}\text { 直流ピーク 值 } \\
35 \mathrm{Vp} \text {, または交 } \\
\text { 流ピーク值 } 35 \mathrm{Vp}, \\
\text { 実効 值 } 25 \mathrm{Vrms} \\
\text { (監視人なし) }\end{array}$ \\
\hline $\begin{array}{l}\text { 始動感度 } \\
\end{array}$ & $260 \Omega$ 以下 & $200 \Omega$ 以下 & $200 \Omega$ 以下 \\
\hline $\begin{array}{l}\text { 遅動 } \\
\text { 時間 }\end{array}$ & 1.5秒以内 & 1.0秒以内 & 2.0秒以内 \\
\hline $\begin{array}{l}\text { 而衝 } \\
\text { 撃性 }\end{array}$ & $\begin{array}{l}\text { 外付け形 : 装 } \\
\text { 置単体で突起物 } \\
\text { のない面を下に } \\
\text { して高さ } 30 \mathrm{~cm} \\
\text { の位置から落下 } \\
\text { 内蔵形 : 交流 } \\
\text { アーク溶接機に } \\
\text { 組み込んだ状態 } \\
\text { での質量が } 25 \mathrm{~kg} \\
\text { 以下のものは高 } \\
\text { さ } 25 \mathrm{~cm}, 25 \mathrm{~kg} \\
\text { を超えるものは } \\
\text { 高さ } 10 \mathrm{~cm} \text { 位 置 } \\
\text { から落下 }\end{array}$ & $\begin{array}{l}\text { 電撃防止装置 } \\
\text { に通電しないな状 } \\
\text { 態で } 30 \mathrm{~cm} \text { の高さ } \\
\text { から衝撃の緩衝 } \\
\text { が起きないよう } \\
\text { に, 突起物がな } \\
\text { い面を下にして } \\
\text { コンクリートま } \\
\text { たは強固な鋼板 } \\
\text { 上に3 回落下さ } \\
\text { せる }\end{array}$ & $\begin{array}{l}\text { • } 25 \mathrm{~kg} \text { 以下の装 } \\
\text { 置は } 25 \mathrm{~cm} \text { の落 } \\
\text { 下に耐える. } \\
\text { • } 25 \mathrm{~kg} \text { を超える } \\
\text { 装置は } 10 \mathrm{~cm} \text { の } \\
\text { 落下に耐える. }\end{array}$ \\
\hline $\begin{array}{l}\text { 絶縁 } \\
\text { 抵抗 }\end{array}$ & $2 \mathrm{M} \Omega$ 以上 & $1 \mathrm{Ms}$ & 以上 \\
\hline 耐電圧 & $\begin{array}{l}\text { 定格入力電圧 } \\
\text { において装置の } \\
\text { 各充電部分と外 } \\
\text { 箱との間に加わ } \\
\text { る電圧の実効値 } \\
\text { の } 2 \text { 倍の電圧に } \\
1,000 \mathrm{~V} \text { 加えて } \\
\text { 得た電圧 (当該 } \\
\text { 加えて得た電圧 } \\
\text { が } 1,500 \mathrm{~V} に \text { 満た } \\
\text { ない場合にあっ } \\
\text { ては, } 1,500 \mathrm{~V})\end{array}$ & $\begin{array}{c}\text { 各充電部と外 } \\
\text { 箱の間で } 1 \text { 分間. } \\
\text { 但し, 最低值は } \\
1,500 \mathrm{~V} \text { とする. } \\
2 \mathrm{E}+1,000 \mathrm{~V} \\
\mathrm{E}: \text { 通常の使用 } \\
\text { 状態における被 } \\
\text { 試験回路に加わ } \\
\text { る最高電圧 } \\
\text { また, 電撃防 } \\
\text { 止装置の電源を } \\
1 \text { 次側からとるも } \\
\text { のに対しては, } \\
\text { その入力側と出 } \\
\text { 力側との間も同様 }\end{array}$ & $\begin{array}{l}\text { 最大定格電圧 } \\
\text { :220 Vの場合 } \\
1,100 \mathrm{~V} \text { (溶接 } \\
\text { 回路と入力回路 } \\
\text { を除く全ての回 } \\
\text { 路との間) } \\
2,200 \mathrm{~V} \text { (溶接 } \\
\text { 回路と入力回路 } \\
\text { との間) }\end{array}$ \\
\hline $\begin{array}{c}\text { ノイズ } \\
\text { 試験 }\end{array}$ & なし & $\begin{array}{l}\text { Tig 高圧発生 } \\
\text { 装置を基準にし, } \\
5 \mathrm{kV} \text { 高圧パル } \\
\text { スを } 1 \text { 秒間隔で } \\
10 \text { 回 }\end{array}$ & なし \\
\hline
\end{tabular}

- AS 1674.2-2007: Safety in welding and allied processes - Electrical.

- AS 60974.1-2006: Arc welding equipment - Welding power sources (Section 11 and 13 for hazard reducing devices).

AS 1674.2-2007: Safety in welding and allied processes Part 2:Electrical は, the Standards Australia Committee EL-019によって策定されている.

AS 1674.2-2007においては，溶接環境を Category A, B，Cの3つに分けている.

Vol. 12, No. 1, pp. 61-66, (2019) 


\section{(1) Category A}

溶接作業者や他の作業者と被溶接部材との絶縁対策が 必要とされる環境, たとえば溶接部材が小さく溶接作業 者が溶接回路の一部となるリスクが小さいベンチトップ 溶接のような場合, あるいは溶接作業者や補助者が導体 と接触しないように配慮されている場合である. 繰り返 し作業においては，そのような環境は通常適切に設計さ れたワークステーション, 溶接教育及び溶接作業資格試 験場に限定される.

(2) Category B

一般の製造現場, 大型の被溶接部材, ビルの鉄骨, 圧 力容器内部, プロセスタンク, 貯蔵タンク, 導電体で囲 まれた空間と船の上が該当する.

(3) Category $\mathrm{C}$

防水堰, 堀, 地下鉱山, 雨中, 一部冠水した場所が含 まれるが，これらに限定されない.

このようなカテゴリーの中で, Category Bにはビル の鉄骨, 圧力容器内部, プロセスタンク, 貯蔵タンク, 導電体で囲まれた空間が含まれていることから，日本で 電撃防止装置を取り付けることが義務づけられている場 所と類似している. 当該場所では下記のような対策を必 要とする.

・可能ならばCategory A とするような措置を講ずる.

- 溶接機の出力側無負荷電圧は直流ピーク值で $113 \mathrm{Vp}$, または交流ピーク值で $68 \mathrm{Vp}$, 交流実効值で $48 \mathrm{Vrms}$ を超えてはならない, 必要に応じて危険低減装置を取 り付ける必要がある.

・溶接作業者が監視人なしで溶接作業を行うときには, 溶接機の出力側無負荷電圧は, 直流ピーク值で $35 \mathrm{Vp}$, または交流ピーク值で $35 \mathrm{Vp}$, 交流実効值で $25 \mathrm{Vrms}$ を超えてはならない。この場合には危険低減装置が必 要となることがある.

・溶接環境が閉鎖空間である場合には, AS/NZS 2865 も適用され，その空間へのアクセスに必要な要件とし て, 緊急の場合にその空間からの避難, 窒息・躓き防 止についての規定が適用される.

またCategory Cにおいては，つぎの対策が必要と なる.

・雨, 水はね, 一部冠水や外部からの要因で, 溶接作業 者や溶接機が濡れると判断される場合には, 溶接作業 開始前に十分な対策が必要となる.

・発汗をできるだけ抑制する環境とするあらゆる対策を 講ずる必要がある.

・溶接作業者の監視人を指名しなければならない，監視 人や溶接作業者の近くの作業者は救護や緊急対応の訓 練を受けていなければならない，監視人は，可能なら ば一人以上の溶接作業者を同時に監視しても良い.

・溶接機の保守点検をこの環境で行ってはならない.

・アークが発生していないときの溶接棒ホルダーと被溶 接部材の電圧は, 直流ピーク值で $35 \mathrm{Vp}$, または交流 ピーク值で $35 \mathrm{Vp}$, 交流実効值で $25 \mathrm{Vrms}$ を超えては ならない。
注：水への曝露を防止する覆い（例：雨や雨滴用屋根）, エアコン，頻繁の着替え（特に綿手袋のライナ）

・ガスメタルアーク溶接：GMAW (Gas metal-arc welding), フラックスコアードアーク : FCAW (Fluxcored arc welding)，ガスタングステンアーク溶接:

GTAW（Gas tungsten-arc welding）用の多くの機 器は, 電流がトリガスイッチとともに流れるため, こ の規格を満足する必要がある.

・被覆アーク溶接: MMAW (Manual metal-arc welding）や類似の作業, 例えばカーボンアークガウ ジングでは，電源は追加の危険低減装置が必要となる ことがある。

・より詳細なアドバイスはWTIS Tech. Notes 7 and 22 より得られる.

上記の危険低減装置については，別表 10 電圧值を超 えてはならず，AS 60974.1の関係規定の要求事項を満 足する必要がある.

危険低減装置の一つである電圧低減装置は, AS 60974.1 に定める要求事項を満足する必要がある。電圧 低減装置には，動作状態を示す表示機構を備えることが 必要で，ランプが使用される場合には，電圧が低下した ときにはランプが点灯する必要がある. AS 60974.1は IEC60974.1, Ed.2.2(2000) Arc welding equipment (ア ーク溶接装置）－Part 1：Welding power sources（溶接 電源）を一部修正したものである.AS 60974.1では電 圧低減装置は，外部溶接回路の抵抗が $200 \Omega$ 超えたと き, 自動的に定格出力側無負荷電圧を Category B で示 す值を超えない電圧に低減する．動作時間は別表20通 りに定められている. 日本の交流アーク溶接機の出力側 無負荷電圧は実効值で $80 \mathrm{Vrms}$ 程度であることから，そ の場合の電圧低減装置の動作時間は2秒と日本の遅動時 間である 1.5 秒と同程度と考えられる. 始動感度も $200 \Omega$ で，日本の $260 \Omega$ と大きな差は無いと考えられる.

以上を踏まえて日本の電撃防止装置とオーストラリア の危険低減装置の一つである電圧低減装置 (Category B, 溶接作業者が監視人なしで単独作業を行う場合*)につい て, 安全に関わる仕様を比較すると表 1 となる. 安全電 圧，遅動時間，耐衝撃性，絶縁抵抗，耐電圧について大 きな差異は見られない。

なお手元トリガスイッチを危険低減装置として使用す るときには, 次の要求を満足する必要がある.

(a) 制御回路の電圧は直流ピーク值 $35 \mathrm{Vp}$ あるいは交 流実効值 25 Vrms 超えてはならない.

（b）スイッチング機構は次を満足しなければならな い.

・溶接作業者がスイッチから手を離すと，速やかに

\footnotetext{
* Welding processes Code of Practice では、溶接作業には適切な危険低 減装置の使用が求められている。AS 1674.2-2007では、監視人あり、監 視人なしでの最大出力側無負荷電圧は、別表 1 に示すように、それぞれ CategoryB の值、Category Cと同一の值となり、監視人がない場合の最 大出力側無負荷電圧は監視人がある場合に比較して、より低い最大出力 側無負荷電圧が求められている。
} 
OFFの位置に戻る.

・スイッチを閉の位置で容易に保持でき, 溶接作業者が 筋力を使わなくとも通常の溶接作業が行える.

・MMAW とカーボンアークガウジングでは, スイッチ がON となるためには2 段階の操作が必要となる. そ のため溶接棒を交換するなどの危険作業中に不用意に スイッチが ON となる可能性が低くなる.

・溶接作業者がスイッチから手を離すと自動的にスイッ チがOFFの位置で停止する.

\section{4 むすび}

感電に起因する休業 4 日以上の死傷労働災害を厚生労 働省の労働災害（死亡・休業 4 日以上）データベースを 用いて分析した. その結果, 従来と同様に業種別では建 設業，製造業が大半を占め，月別では夏季に多発し，労 働者規模が 30 人未満で多く発生し, 設備別では電力設 備, 送配電線, その他の電気設備, アーク溶接機が上位 を占めていることが確認できた。労働者の年齢では 30 代後半, 60 代前半の作業者の感電災害が多発していた。

交流アーク溶接機の安全装置には電撃防止装置が使用 されているが, 韓国, オーストラリアとの比較を行った. 韓国は日本の電撃防止装置と類似した機構の安全装置を 使用しているが，オーストラリアはIECの規格を基本と した危険低減装置が使用されていた，我が国の電撃防止 装置と韓国, オーストラリアのアーク溶接機の安全装置 とに感電災害防止に関わる仕様において大きな差異が無 いことが確認された。

\section{文献}

1）職場のあんぜんサイト：労働災害（死亡・休業 4 日以上） データベース

http://anzeninfo.mhlw.go.jp/anzen_pgm/SHISYO_FND. aspx（平成 30 年 8 月 27 日確認)

2）保護装置自立安全基準公示(韓国労働部公示第2015-94号: 2015.12.24一部改訂) [別表2] 電撃防止装置の性能基準(第 5 条関連）及び[別表2-2]電撃防止装置の試験方法

3) AS1674.2-2007: Safety in welding and allied processes Part 2: Electrical

参考資料

別表 1 最大出力側無負荷電圧

\begin{tabular}{|c|c|}
\hline 作業環境 & 出力側無負荷電圧 \\
\hline Category A & $\begin{array}{l}\text { 直流ピーク值 } 113 \mathrm{Vp}, \text { または交流ピー } \\
\text { ク值 } 113 \mathrm{Vp} \text {, 実効值 } 80 \mathrm{Vrms}\end{array}$ \\
\hline $\begin{array}{l}\text { Category B } \\
\text { (監視人あり) }\end{array}$ & $\begin{array}{l}\text { 直流ピーク值 } 113 \mathrm{Vp}, \text { または交流ピー } \\
\text { ク值 } 68 \mathrm{Vp}, \text { 実効值 } 48 \mathrm{Vrms} \\
\end{array}$ \\
\hline $\begin{array}{l}\text { Category B } \\
\text { (監視人なし) } \\
\end{array}$ & $\begin{array}{l}\text { 直流ピーク值 } 35 \mathrm{Vp}, \text { または交流ピーク值 } \\
35 \mathrm{Vp} \text {, 実効值 } 25 \mathrm{Vrms}\end{array}$ \\
\hline Category C & $\begin{array}{l}\text { 直流ピーク值 } 35 \mathrm{Vp}, \text { または交流ピーク } \\
\text { 值 } 35 \mathrm{Vp} \text {, 実効值 } 25 \mathrm{Vrms}\end{array}$ \\
\hline $\begin{array}{l}\text { 操作者のための強 } \\
\text { 化された防護を有 } \\
\text { する機械的に保持 } \\
\text { されるトーチ }\end{array}$ & $\begin{array}{l}\text { 直流ピーク值 } 141 \mathrm{Vp}, \text { または交流ピー } \\
\text { ク值 } 141 \mathrm{Vp} \text {, 実効值 } 100 \mathrm{Vrms}\end{array}$ \\
\hline プラズマ切断 & 直流ピーク值 $500 \mathrm{Vp}$ \\
\hline
\end{tabular}

別表2 電圧低減装置要求

\begin{tabular}{|c|c|c|}
\hline $\begin{array}{l}\text { 低減していない出力側無負荷電 } \\
\text { 圧 }\end{array}$ & \begin{tabular}{|l} 
低減出力側無負荷 \\
電圧
\end{tabular} & $\begin{array}{c}\text { 動作時間 } \\
\text { (sec) }\end{array}$ \\
\hline $\begin{array}{l}\text { 操作者のための強化された防護 } \\
\text { を有する機械的に保持されるト } \\
\text { ーチでの許容電圧とCategory A } \\
\text { での許容電圧との間 }\end{array}$ & $\begin{array}{l}\text { Category Bの許容 } \\
\text { 電圧 }\end{array}$ & 0.3 \\
\hline Category A と Category B との間 & $\begin{array}{l}\text { Category Bの許容 } \\
\text { 電圧 }\end{array}$ & 2 \\
\hline
\end{tabular}

注記＼cjkstart直流溶接電源で $113 \mathrm{~V}$ を超える場合は， $0.3 \mathrm{~s}$ の動作時間 が必要 


\section{Investigation on present labour accidents due to electric shock \\ and comparison of safety devices for preventing electric shock accidents used for arc welding equipment in foreign countries}

by

Hajime TOMITA*1 and Kwangseok CHOI*2

Labour accidents caused by electric shock which are absent from their work for four days or more were analyzed based on data base disclosed by Ministry of Health, Labour and Welfare between 2006 to 2015. As a result, the condition of labour accidents caused by electric shock in the qualitative expression was not very much change compared to that before 1998, and arc welders were one of the main causes of electric shock accidents.

Safety devices in South Korea and Australia, which are similar to automatic electric shock preventive device for AC arc welding equipment in Japan, were compared with those in Japan. As a result, the specifications on starting sensitivity, delay time and safety voltage for AC arc welding equipment in South Korea and Australia did not differ much from those in Japan.

Key Words: electric shock, labour accident data base, AC arc welding equipment, automatic electric shock preventive device for $\mathrm{AC}$ arc welding equipment, hazard-reducing device, South Korea and Australia

*1 Center of Research Promotion and International Affairs, National Institute of Occupational Safety and Health

*2 Electrical Safety Research Group, National Institute of Occupational Safety and Health 